\title{
Screening of Sorghum (Sorghum bicolor (L.) Moench) Mutant Lines for Shootfly Resistance (Atherigona soccata Rondani)
}

\author{
M. Navinkumar ${ }^{1 *}$, G. Girish ${ }^{2}$, M. B. Ashok ${ }^{3}$, S. Muniswamy ${ }^{4}$, \\ L. N. Yogeesh ${ }^{2}$ and S. M. Prashant ${ }^{2}$ \\ ${ }^{1}$ College of Agriculture Raichur, University of Agriculture Sciences, Raichur, India \\ ${ }^{2}$ Agriculture Research Station, Hagari, India \\ ${ }^{3}$ Bhabha Atomic Research Centre Trombay, Mumbai, India \\ ${ }^{4}$ Agriculture Research Station, Kalburgi, India \\ *Corresponding author
}

\section{A B S T R A C T}

\begin{tabular}{|l|}
\hline Key w or d s \\
$\begin{array}{l}\text { Sorghum, } \\
\text { Sorghum bicolor }\end{array}$ \\
\hline Article Info \\
\hline $\begin{array}{l}\text { Accepted: } \\
14 \text { November } 2020 \\
\text { Available Online: } \\
10 \text { December } 2020\end{array}$ \\
\hline
\end{tabular}

The present investigation conducted to screen sorghum 100 mutants along with 7 checks of sorghum for resistance against sorghum shoot fly (Atherigona soccata Rondani) in augmented block design at Agriculture research station Hagari, during late kharif 2019 under natural infestation condition. The screening results revealed that 5 mutant lines IS925-21(10\%), IS925-124(7.69\%), IS925-125(8.69\%), PV-21(5\%) and PV-51(9.09\%) were highly resistant compared to resistant check IS-2312 (12.5\%). These mutant lines exhibit comparatively lower number of eggs per plant and minimum dead heart formation. These lines can be used for further conformation and can be used in future tolerance breeding programs.

\section{Introduction}

Sorghum [Sorghum bicolor (L.) Moench] a cultivated diploid $(2 \mathrm{n}=20)$ tropical cereal $\mathrm{C}_{4}$ grass plant, is the fifth most important cereal crop grown in the world. Sorghum is called as camel of crops due to its high tolerance to water and temperature stress and also it had high photosynthesis efficiency.

India is a major sorghum growing country in the world, ranks first in acreage and second in production next to United States of America. In India sorghum grown in an area about 4.09 $\mathrm{m}$ ha with production of $3.48 \mathrm{~m}$ tonnes and productivity of $845 \mathrm{~kg} / \mathrm{ha}$. In Karnataka it is grown in 0.94 million hectares with production of 0.89 million tonnes and productivity of $945 \mathrm{~kg} / \mathrm{ha}$ (INDIASTAT, 2019). Major sorghum growing districts of Karnataka are Kalaburgi, Raichur, Koppal, Belagavi, Ballari and Vijayapur. Mutation is recognized as one of the driving forces of evolution. Induced mutation breeding is relatively quicker method to create variability in different plants (Camargo et al., 2000). To get high frequency of gene mutation and chromosomal alteration gamma rays are used, 
which creates variation within the crop variety (Thapa, 2004).

Insect pests cause much reduction in yield levels, among which shoot fly is a major one. Shoot fly is an important pest of sorghum in Asia, Africa and Mediterranean Europe. Maximum yield losses of $80-90 \%$ in grain yield and $68 \%$ in fodder yield have been reported (Kahate, 2014). Its incidence was higher in late-sown crops in the rainy and post rainy (rabi) seasons because of buildup of shoot fly populations on the early-sown crops (Balikai and Bhagwat, 2009). Adoption of chemical methods is not economically feasible for resource poor farmers and Pest damage of crop ranges from 7-30 days after germination, hence very little or no time to take control measures. More over this method is polluting soil, water, food and fodder. Therefore, utilization of host plant resistance in mutants is the most realistic alternative method for reducing losses caused by the insects.

\section{Materials and Methods}

Two varietal seeds viz., IS925 and Phule Vasudha of sorghum lines were irradiated with 300 Gy gamma rays and some of the irradiated seeds are also treated with $0.1 \%$ Sodium azide (50 Gamma irradiated and 50 Gamma irradiated + chemical treated) at equilibrium moisture content of $8 \%$. The $\mathrm{M}_{1}$ and $\mathrm{M}_{2}$ progenies were raised. 50 mutants from IS925 variety(25 irradiated and 25 irradiated + chemical treated) and 50 mutants from Phule Vasudha variety(25 irradiated and
25 irradiated + chemical treated) were selected from the $\mathrm{M}_{2}$ generation and used as seed material along with checks viz., IS2312(resistant), DJ-6514(susceptible), GS-23, DSV-4, E-36-1, DJ-6514, SPV-86, and M-351 for present investigation.

To attain uniform shoot fly pressure under field conditions the interlard-fish meal technique (Nwanzae, 1997) was followed for screening resistance (Plate 1). Susceptible cultivar (DJ 6514) was sown 20 days before sowing the test material. This was done to allow for multiplication of shoot fly for one generation (Plate 2). Seven days after seedlings emergence, moistened fish meal was spread uniformly in four blocks covering all the test material to attract the emerging shoot flies from Infester rows. The plant protection measures were avoided until the shoot fly infestation period was complete. Four normal parameters used in shootfly screening studies were recorded viz., per cent dead heart, oviposition, leaf glossiness, Seedling vigour.

Per cent dead heart: Dead heart counts were recorded at 21 days after emergence. Dead heart was expressed in terms of percentage (Nimbalkar and Bapat 1987). Dead heart due to shootfly incidence shown in plate 3 .

Dead heart $(\%)=\frac{\text { Number of shoots with dead heart }}{\text { Total number of shoots }} \times 100$

The following rating scale was used to classify the genotypes into different categories, (Nimbalkar and Bapat 1987).

\begin{tabular}{|l|l|}
\hline \multicolumn{1}{|c|}{ Rating } & Reaction \\
\hline $\mathbf{0}-\mathbf{1 0} \%$ dead heart & Highly resistant \\
\hline $\mathbf{1 0}-\mathbf{2 0} \%$ dead heart & Resistant \\
\hline $\mathbf{2 0}-\mathbf{3 0} \%$ dead heart & Moderately resistant \\
\hline $\mathbf{3 0}-\mathbf{5 0} \%$ dead heart & Susceptible \\
\hline Above 50 \% dead heart & Highly susceptible \\
\hline
\end{tabular}


Oviposition: Total number of plants with eggs in each entry was recorded at 7 DAE (Plate4). The observations on units were expressed in terms of percentage (Kamatar et al., 2010).

Oviposition $(\%)=\frac{\text { Number of plants with eggs }}{\text { Total number of plants }} \times 100$

Leaf glossiness: Intensity of glossiness was recorded at 7 days after emergence (DAE) on 1 to 5 scale where 5 represents high intensity of glossiness and 1 as non-glossy as shown in plate 5. Leaf glossiness was scored in the morning hours when there was maximum reflection of light (Kamatar et al., 2010).

Seedling vigour: Seedling vigour (height, leaf growth and robustness) was scored at 16 DAE on a 1-5 scale, where 5-High vigour (plants showing maximum height, leaf expansion and robustness) and 1-low vigour (plants showing minimum growth, less leaf expansion and poor adaptation) (Kamatar et al., 2010).

\section{Results and Discussion}

The per cent dead heart formation observed least in mutants PV-21(5\%) compared to resistant check IS-2312 (12.5\%). The maximum per cent dead heart formation observed in mutant IS925-4 (70\%) compared to the susceptible check DJ-6514 shows 52.63 $\%$ dead heart formation.

Among mutant lines screened 5 mutants are highly resistant $(0-10 \%), 44$ mutants are resistant (11-20\%), 17 Mutants are Moderately resistant (21-30\%), 26 mutants are Susceptible (31-50\%), 8 mutants are Highly susceptible $(>50 \%)$ which are presented in the Table 1. Similar results also observed by Kamatar et al., (2010) and Kiran (2014).

Table.1 Classification of sorghum mutant lines based on per cent Dead heart formed due to shoot fly incidence

\begin{tabular}{|c|c|c|}
\hline & & Mutants \\
\hline Reaction & IS925 & Phule Vasudha \\
\hline $\begin{array}{l}\text { Highly resistance } \\
(0-10 \%)\end{array}$ & IS925-21, IS925 -124, IS925-125, & PV-21, PV-51. \\
\hline $\begin{array}{l}\text { Resistance } \\
(11-20 \%)\end{array}$ & $\begin{array}{l}\text { IS925- 24, IS925-19, IS925-9, IS925-16, } \\
\text { IS925-3, IS925-16, IS925-118, IS925-96, } \\
\text { IS925-127, IS925-114, IS925-RD-76, } \\
\text { IS925-116, IS925-RV-3, IS925-RV-16, } \\
\text { IS925-RV-7, IS925-RD-17, IS925-123, } \\
\text { IS-2312. }\end{array}$ & $\begin{array}{l}\text { PV-22, PV-24, PV-11, PV-14, PV-2, PV-15, PV-1, } \\
\text { PV-17, PV-3, PV-13, PV-16, PV-6, PV-5(E), PV- } \\
\text { RD-21, PV-47, PV-RD-5, PV-RD-20, PV-RD-13, } \\
\text { PV-16, PV-RD-48, PV-22, PV-RD-10, PV-2, PV- } \\
\text { 15, PV-RD-15, PV-29, PV-60, }\end{array}$ \\
\hline $\begin{array}{l}\text { Moderately } \\
\text { resistance } \\
(21-30 \%)\end{array}$ & $\begin{array}{c}\text { IS925-1, IS925-25, IS925-5, GS-23, SPV- } \\
86 .\end{array}$ & $\begin{array}{l}\text { PV-48, PV-4, PV-8, PV-18, PV-25, PV-26, PV-7, } \\
\text { PV-RD-36, PV-57, PV-37, PV-61, IS925 -28, PV- } \\
\text { RD-53, PV-14. }\end{array}$ \\
\hline $\begin{array}{l}\text { Susceptible } \\
(30-50 \%)\end{array}$ & $\begin{array}{l}\text { IS925-8, IS925-17, IS925-13, IS925-14, } \\
\text { IS925-11, IS925-23, IS925-20, IS925-15, } \\
\text { IS925-7, IS925-10, IS925-4-1, IS925 - } \\
\text { RD-63, IS925-120, IS925 -115, IS925 - } \\
\text { 41, IS925 -23, IS925-110, IS925 -RD-44, } \\
\text { M-35-1, E-36-1, DSV-4. }\end{array}$ & $\begin{array}{c}\text { PV-23, PV-10, PV-9, PV-5, } \\
\text { PV-19, PV-27, PV-RD-35, PV-RD-15 }\end{array}$ \\
\hline $\begin{array}{l}\text { Highly } \\
\text { susceptible } \\
(>50 \%)\end{array}$ & $\begin{array}{l}\text { IS925-2, IS925-12, IS925-4, IS925-22, } \\
\text { IS925-6, IS925 -3, IS925 -38, DJ-6514. }\end{array}$ & PV-20. \\
\hline
\end{tabular}


Table.2 Mean performances of $\mathrm{M}_{3}$ sorghum mutant lines for shoot fly incidence

\begin{tabular}{|c|c|c|c|c|c|}
\hline SL. No & MUTANTS & $\begin{array}{c}\text { Dead } \\
\text { heart } \%\end{array}$ & $\begin{array}{c}\text { Seedling } \\
\text { Vigour }\end{array}$ & Glossiness & Oviposition \% \\
\hline & P+C (IS925) & & & & \\
\hline 1 & IS925-8 & 37.5 & 3 & 2 & 52.38 \\
\hline 2 & IS925-17 & 33.33 & 4 & 3 & 46.66 \\
\hline 3 & IS925-13 & 34.48 & 3 & 3 & 40 \\
\hline 4 & IS925-2 & 52.94 & 3 & 4 & 64.7 \\
\hline 5 & IS925-24 & 16.66 & 3 & 1 & 27.77 \\
\hline 6 & IS925-19 & 18.18 & 3 & 2 & 36.36 \\
\hline 7 & IS925-12 & 54.54 & 2 & 3 & 72.72 \\
\hline 8 & IS925-14 & 33.33 & 2 & 4 & 100 \\
\hline 9 & IS925-4 & 70 & 2 & 3 & 90 \\
\hline 10 & IS925-11 & 41.17 & 4 & 4 & 47.05 \\
\hline 11 & IS925-23 & 44.44 & 4 & 3 & 55.55 \\
\hline 12 & IS925-20 & 40 & 2 & 2 & 80 \\
\hline 13 & IS925-15 & 45 & 3 & 4 & 55 \\
\hline 14 & IS925-1 & 22.22 & 4 & 3 & 44.44 \\
\hline 15 & IS925-25 & 24 & 3 & 2 & 32 \\
\hline 16 & IS925-22 & 66.66 & 2 & 4 & 57.12 \\
\hline 17 & IS925-5 & 25 & 2 & 4 & 25 \\
\hline 18 & IS925-21 & 10 & 2 & 2 & 20 \\
\hline 19 & IS925-9 & 14.28 & 3 & 2 & 14.28 \\
\hline 20 & IS925-7 & 45.83 & 3 & 1 & 54.16 \\
\hline 21 & IS925-6 & 52.38 & 3 & 2 & 57.14 \\
\hline 22 & IS925-16 & 20 & 3 & 2 & 33.33 \\
\hline 23 & IS925-3 & 13.33 & 3 & 2 & 26.66 \\
\hline 24 & IS925-10 & 50 & 1 & 1 & 53.33 \\
\hline \multirow[t]{2}{*}{25} & IS925-18 & 34.53 & 3 & 3 & 47.62 \\
\hline & $\mathrm{P}+\mathrm{C}(\mathrm{PV})$ & & & & \\
\hline 26 & PV - 23 & 40 & 3 & 3 & 60 \\
\hline 27 & PV - 22 & 14.28 & 3 & 3 & 28.57 \\
\hline 28 & PV - 24 & 15 & 4 & 4 & 25 \\
\hline 29 & PV - 19 & 40 & 3 & 2 & 53.33 \\
\hline 30 & PV - 11 & 16.66 & 4 & 3 & 27.77 \\
\hline 31 & PV - 14 & 20 & 1 & 2 & 60 \\
\hline 32 & PV - 26 & 22.22 & 4 & 2 & 33.33 \\
\hline 33 & PV - 7 & 21.05 & 4 & 3 & 35 \\
\hline 34 & PV - 2 & 20 & 3 & 3 & 33.33 \\
\hline 35 & PV - 15 & 19.04 & 3 & 1 & 30 \\
\hline 36 & PV - 20 & 60 & 3 & 3 & 75 \\
\hline 37 & PV - 4 & 25 & 3 & 3 & 30 \\
\hline 38 & PV - 8 & 23.07 & 4 & 4 & 38.46 \\
\hline 39 & PV - 10 & 33.33 & 2 & 1 & 66.66 \\
\hline 40 & PV - 1 & 14.81 & 4 & 3 & 22.22 \\
\hline 41 & PV - 17 & 10.71 & 4 & 3 & 17.85 \\
\hline
\end{tabular}




\begin{tabular}{|c|c|c|c|c|c|}
\hline 42 & PV - 3 & 16.66 & 1 & 1 & 33.33 \\
\hline 43 & PV - 18 & 25 & 2 & 1 & 75 \\
\hline 44 & PV - 9 & 50 & 1 & 2 & 66.66 \\
\hline 45 & $P V-25$ & 25 & 2 & 2 & 40 \\
\hline 46 & PV - 13 & 16.66 & 2 & 2 & 33.33 \\
\hline 47 & PV - 21 & 5 & 5 & 4 & 15 \\
\hline 48 & PV - 5 & 36.36 & 3 & 2 & 54.54 \\
\hline 49 & PV - 16 & 16.66 & 2 & 3 & 27.77 \\
\hline \multirow[t]{2}{*}{50} & PV - 6 & 17.39 & 1 & 2 & 26.08 \\
\hline & P(IS925) & & & & \\
\hline 51 & IS925 -124 & 7.69 & 5 & 4 & 15.38 \\
\hline 52 & IS925 -16-1 & 15 & 4 & 3 & 25 \\
\hline 53 & IS925-4 -1 & 50 & 2 & 3 & 64.28 \\
\hline 54 & IS925 -125 & 8.69 & 4 & 3 & 17.39 \\
\hline 55 & IS925 -RD-63 & 40 & 3 & 2 & 80 \\
\hline 56 & IS925 -120 & 40 & 4 & 2 & 52 \\
\hline 57 & IS925 -118 & 17.39 & 4 & 3 & 26.08 \\
\hline 58 & IS925 -3 & 58.82 & 1 & 3 & 70.58 \\
\hline 59 & IS925 -115 & 47.36 & 3 & 3 & 57.89 \\
\hline 60 & IS925 -28 & 23.07 & 4 & 4 & 34.61 \\
\hline 61 & IS925 -110 & 31.25 & 4 & 4 & 43.75 \\
\hline 62 & IS925 -96 & 15.38 & 4 & 2 & 23.07 \\
\hline 63 & IS925 -127 & 20 & 2 & 1 & 60 \\
\hline 64 & IS925 -RD-44 & 32.25 & 4 & 4 & 41.93 \\
\hline 65 & IS925 -114 & 20.83 & 4 & 3 & 29.16 \\
\hline 66 & IS925 -RD-76 & 25 & 4 & 4 & 37.5 \\
\hline 67 & IS925 -41 & 38.09 & 3 & 3 & 47.61 \\
\hline 68 & IS925 -116 & 14.81 & 3 & 4 & 22.22 \\
\hline 69 & IS925 -RV-3 & 13.04 & 4 & 4 & 21.73 \\
\hline 70 & IS925 -23 & 43.75 & 1 & 3 & 56.25 \\
\hline 71 & IS925 -RV-16 & 15.38 & 3 & 4 & 23.07 \\
\hline 72 & IS925 -RV-7 & 13.63 & 4 & 2 & 22.72 \\
\hline 73 & IS925 -RD-17 & 15.15 & 4 & 3 & 21.21 \\
\hline 74 & IS925 -38 & 60 & 1 & 4 & 80 \\
\hline \multirow[t]{2}{*}{75} & IS925 -123 & 16.66 & 2 & 2 & 27.77 \\
\hline & $\mathbf{P}(\mathbf{P V})$ & & & & \\
\hline 76 & PV-48 & 30.30 & 3 & 3 & 36.36 \\
\hline 77 & PV-5(E) & 17.85 & 3 & 2 & 25 \\
\hline 78 & PV-RD-21 & 15.38 & 2 & 2 & 23.07 \\
\hline 79 & PV-RD-36 & 26.66 & 2 & 4 & 33.33 \\
\hline 80 & PV-57 & 27.58 & 3 & 3 & 31.03 \\
\hline 81 & PV-27 & 31.03 & 3 & 2 & 37.93 \\
\hline 82 & PV-37 & 25.92 & 3 & 2 & 33.33 \\
\hline 83 & PV-47 & 14.70 & 4 & 3 & 20.58 \\
\hline 84 & PV-61 & 26.08 & 4 & 4 & 34.78 \\
\hline 85 & PV-RD-5 & 15.15 & 4 & 4 & 18.18 \\
\hline 86 & PV-RD-35 & 41.66 & 4 & 3 & 50 \\
\hline
\end{tabular}




\begin{tabular}{|c|c|c|c|c|c|}
\hline 87 & PV-RD-20 & 14.28 & 4 & 4 & 21.42 \\
\hline 88 & PV-RD-13 & 14.28 & 4 & 3 & 20 \\
\hline 89 & PV-16 & 20.68 & 4 & 2 & 27.58 \\
\hline 90 & PV-RD-48 & 26.47 & 4 & 1 & 32.35 \\
\hline 91 & PV-22 & 11.11 & 4 & 3 & 18.518 \\
\hline 92 & PV-51 & 9.09 & 3 & 3 & 18.18 \\
\hline 93 & PV-RD-10 & 17.64 & 4 & 4 & 23.52 \\
\hline 94 & PV-2 & 11.76 & 4 & 3 & 17.64 \\
\hline 95 & PV-RD-53 & 29.03 & 4 & 3 & 35.48 \\
\hline 96 & PV - 41 & 21.87 & 4 & 4 & 28.12 \\
\hline 97 & PV-15 & 17.14 & 4 & 4 & 22.85 \\
\hline 98 & PV-RD-15 & 31.03 & 4 & 4 & 37.93 \\
\hline 99 & PV-29 & 13.33 & 4 & 3 & 20 \\
\hline \multirow[t]{2}{*}{100} & PV-60 & 16.66 & 4 & 4 & 23.33 \\
\hline & CHECKS & & & & \\
\hline 1 & DJ-65-14 (S) & 52.63 & 3 & 2 & 78.94 \\
\hline 2 & IS-2312 (R) & 12.5 & 4 & 3 & 26.08 \\
\hline 3 & GS-23 & 29.16 & 4 & 3 & 41.66 \\
\hline 4 & M-35-1 & 36.36 & 3 & 2 & 60 \\
\hline 5 & SPV-86 (S) & 29.16 & 4 & 2 & 41.66 \\
\hline 6 & E-36-1 (R) & 38.09 & 3 & 2 & 55 \\
\hline \multirow[t]{6}{*}{7} & DSV-4 (R) & 40 & 3 & 3 & 54.54 \\
\hline & CD@5\% & & & & \\
\hline & $\mathbf{C} \mathbf{i}-\mathbf{C} \mathbf{j}$ & 8.4 & 0.93 & 0.92 & 15 \\
\hline & BiVi-BiVj & 18 & 1.99 & 1.96 & 32 \\
\hline & BiVi-BjVj & 16.8 & 1.86 & 1.83 & 30 \\
\hline & Ci-Vl & 13.9 & 1.53 & 1.51 & 24 \\
\hline
\end{tabular}

P- Physically irradiated $\quad \mathrm{P}+\mathrm{C}-$ Physically irradiated and chemically treated

Ci-Cj- For two check means

$\mathrm{BiVi-BiVj-For} \mathrm{two} \mathrm{test} \mathrm{genotype} \mathrm{means} \mathrm{in} \mathrm{same} \mathrm{block}$

$\mathrm{BiVi-BjVj-For} \mathrm{any} \mathrm{two} \mathrm{entries} \mathrm{means} \mathrm{in} \mathrm{the} \mathrm{same} \mathrm{block}$

$\mathrm{Ci}-\mathrm{Vl}-\mathrm{For}$ means between a check and a test genotype

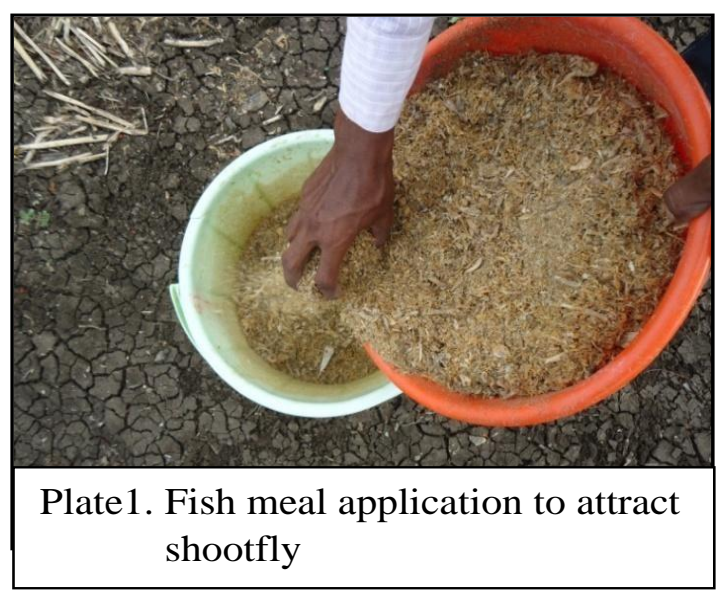

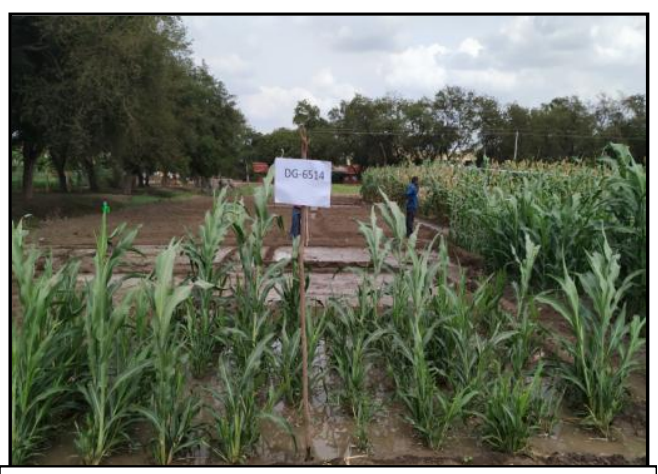

Plate 2. susceptible cultivar sown for multiplication of shoot 


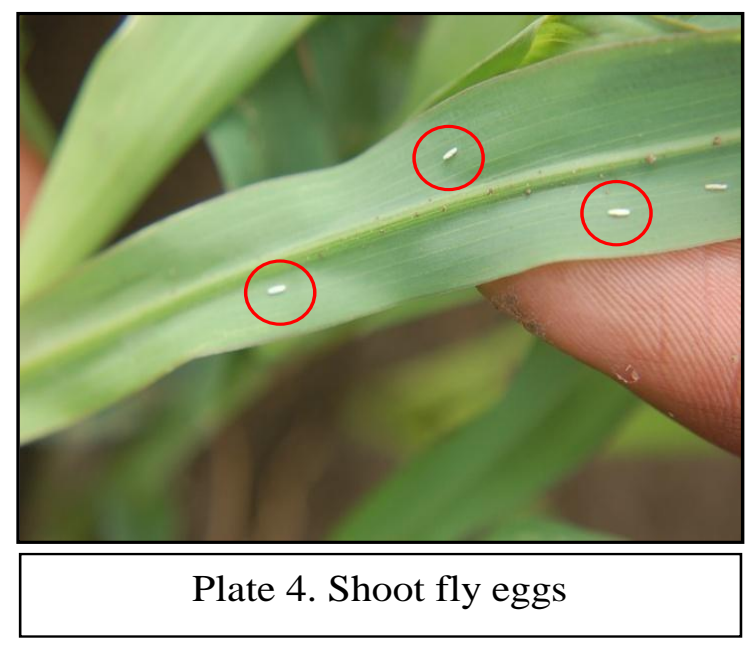

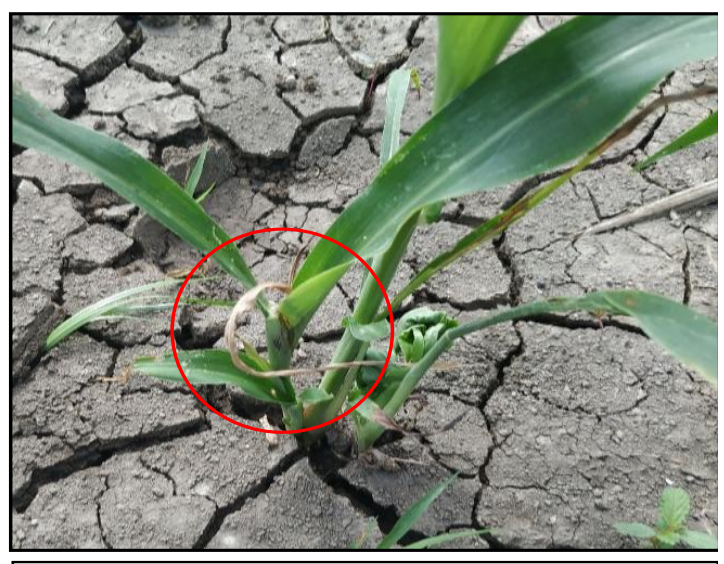

Plate 3. Deadhearts due to shoot fly

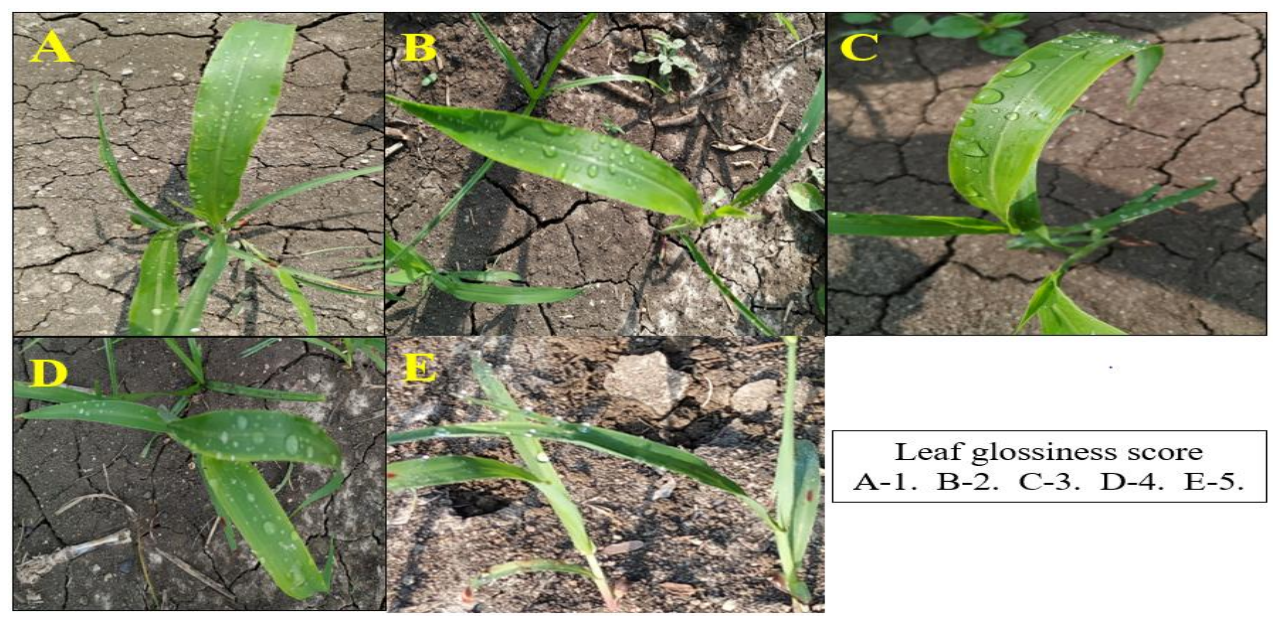

Least oviposition per cent (least number of egg laying) observed in the mutant IS925-9 (14.28\%) compared to resistant check IS2312 (26.08\%). Highest oviposition observed in mutant IS925-14(100\%) compared to susceptible check DJ-6514 (78.94\%). These results are similar to findings of Kumar et al., (2008) and Chandra et al., (2018).

Seedling vigour was score among mutants reviled that, only two mutants PV-21 and IS925-124 showed high vigorous score 5, 41 mutants show score 4, 32 mutants show score 3, 17 mutants show score 2 and 8 mutants show score 1 .
The minimum seedling vigour score observed in mutant was 1 and categorized as susceptible against shoot fly. The finding of the present investigation is similar with the finding of Prasad (2015) who observed that higher plant vigour in sorghum was responsible for imparting resistance to shootfly. Similarly, Sharma and Nwanze (1997) have also found plant vigour as an important morphological character for imparting resistance to shoot fly (Table 2).

Among mutants studied, none of the genotypes shows high glossiness 5 score, but 27 mutants show score 4, 37 mutants show score 3, and 27 mutants show score 2 . The 
least glossy score 1 was observed in 9 mutants.

Glossy leaf influences the host preference leading to less egg laying and lower deadheart percentage. The presence of glossy surface on adaxial and abaxial surface causes in the fall down of eggs to soil before hatching and results in reduction in maggot population. These findings of Kamatar et al., (2010), Aruna et al., (2011) and Sonalkar and Pagire (2017).

The mutants showing high seedling vigour and glossiness are less prone to shootfly because of their olfactory or gustatory responses to the insects and also high vigorous plants makes it difficult for maggot to reach the stem. Less vigorous plants emitted higher dose of chemicals which attract the shoot fly. When the barrel shaped eggs hatched on the vigorous seedlings, maggots need longer time to reach meristematic tissue. Seedling vigour and glossiness acts as obstacle for maggots to reach meristematic tissues. It will fall down to soil results in less maggot population.

In conclusion the screening for shoot fly resistance with interlard fish-meal technique in 100 mutant lines along with two checks viz., IS-2312 (Resistance) and DJ6514(Susceptible) studies revealed that, the mutants IS 925-21, IS 925 -124, IS 925-125, PV-21 and PV-51 shown resistant reaction, in respect of shootfly resistance component characters viz., oviposition, deadheart, glossiness and seedling vigour which suggesting that these lines were tolerant to shootfly infestation. These lines can be used for further conformation and used in future tolerance breeding programs.

\section{References}

Aruna, C., Bhagwat, V. R., Madhusudhana, R., Sharma, V., Hussain, T., Ghorade,
R. B., Khandalkar, H. G., Audilakshmi, S. and Seetharama, N., 2011, Identification and validation of genomic regions that affect shoot fly resistance in sorghum [Sorghum bicolor (L.) Moench]. Theor. Appl. Genet., 122: 1617-1630.

Balikai, R. A. and Bhagwat, V.R., 2009, Evaluation of integrated pest management components for the management of shoot fly, shoot bug and aphid in rabi sorghum. Karnataka J. Agric. Sci., 22(3): 532-534.

Camargo, C. O., Neto, A. T., Filho, A. F. and Felico, J. C., 2000, Genetic control of aluminium tolerance in mutant lines of the wheat cultivar Anahuac. Euphytica., 114: 47-53.

Chandra, B., Hemant, S., Lekha, Azad, M., Lakhawat. S. S. and Mahla. M. k., 2018, Screening of different sorghum varieties for resistance against sorghum shootfly. Indian J. Appl. Ent. 32 (1): 42-47.

INDISTSAT 2019, India sorghum production and utilization. New Delhi. Available on http:// Www.indiastat.com/agriculture/2/foodg rains/17180/jowargreatmillet.

Kamatar, M. Y., Patil, A. M., Yadwab, A., Salimath, P. M. and Rao, T. S., 2010, Correlation and path analysis in parents and hybrids for resistance to sorghum shoot fly [Atherigona soccata (Rondani)]. Int. J. Plant Sci., 5(2): 399-403.

Kahate, N. S., Raut, S. M., Ulemale, P. H. and Bhogave, A. F. 2014. Management of sorghum shoot fly. popular kheti., 2: 72-74.

Kiran, S. B., 2014, Stability analysis and screening for shoot fly tolerance in advanced breeding lines of sorghum. M. Sc. (Agri) Thesis, Univ. of Agric. Sci. Raichur, (India).

Kumar, A. A., Reddy, B. V. S., Sharma, H. C. 
and Ramaiah, B., 2008. Shoot fly (Atherigona soccata) resistance in improved grain sorghum hybrids. $J$. SAT. Agril. Res., 6: 1-4.

Nimbalkar, V. S. and Bapat, D. R., 1987, Genetic analysis of shoot fly resistance under high level of shoot fly infestation in sorghum. J. Maharahstra Agril. Univ, 12: 331-334.

Nwanze, K.F., 1997, Integrated management of stemborers of sorghum and pearl millet. Int. J. Trop. INSECT SC, 17(1): $1-8$.

Prasad, G. S., Babu, K. S., Subbarayudu, B., Bhagwat, V. R. and Patil, J. V., 2015, Identification of sweet sorghum accessions possessing multiple resistance to shoot fly (Atherigona soccata Rondani) and stem borer (Chilo partellus swinhoe). Sugar Tech., 17: 173-180.

Sonalkar, V. U. and Pagire, K. S., 2017, Reaction of Grain Sorghum Varieties to Major Pests in Vidarbha Region. Int. J. Curr. Microbiol. App. Sci., 6(2): 891-898.

Thapa, C. B., 2004, Effect of acute exposure of gamma rays on seed germination and seedling growth of Pinus kesiagord and $P$. wallichiana. Our Nat., 2: 13-17.

\section{How to cite this article:}

Navinkumar, M., G. Girish, M. B. Ashok, S. Muniswamy, L. N. Yogeesh and Prashant, S. M. 2020. Screening of Sorghum (Sorghum bicolor (L.) Moench) Mutant Lines for Shootfly Resistance (Atherigona soccata Rondani). Int.J.Curr.Microbiol.App.Sci. 9(12): 1877-1885. doi: https://doi.org/10.20546/ijcmas.2020.912.223 